\section{The University of Illinois at Urbana-}

Champaign (UIUC) has received two grants from the Institute of Museum and Library Services (IMLS). The rst grant of $\$ 91,562$ is for the project Metadata for You and Me: A Training Program for Shareable Metadata. In partnership with Indiana University, UIUC s University Library will develop and conduct a training program to address the needs of library, museum, and cultural heritage professionals in the creation, development, and use of shareable descriptive metadata. The second grant award of $\$ 249,983$ is for the project Building a Framework for Preservation and Access Decision Making for Audio-Visual Collections. UIUC s University Library will develop and test an audio-visual self-assessment program for preservation of and access to endangered recorded sound and moving image collections.

\section{Purdue University has received a \$1 million} gift to build its rst archives documenting the lives and accomplishments of the university $s$ women. The Susan Bulkeley Butler Women s Archives will provide resources visitors can use to learn about Purdue history and the key roles women faculty and alumnae have played in the university s growth. It also will be a site for seminars and exhibits in its Stewart Center location. The archives will include an oral history program featuring recorded interviews with key women leaders, an acquisition program to gain important materials through donations and purchases, and a lecture series focused on women leaders at Purdue. The archives also will provide grants for researchers from around the country to use the archives and provide support for a staff member specializing in women s studies to work in the archives.

Ed. note: Send your news to: Grants \& Acquisitions, C\&RL News, 50 E. Huron St., Chicago, IL 60611-2795; e-mail: agalloway@ala.org.

\section{Acquisitions}

An archive of materials chronicling the history of Japanese and East Asian 1m, collected by the renowned documentary lmmaker and Im historian Makino Mamoru, has been acquired by Columbia University s C. V. Starr East Asian Library. The collection contains material dating back to the earliest moving pictures in Japan and the start of domestic $1 \mathrm{~m}$ production during the Meiji period (1868 1912), and continues to the present. It includes a wealth of rare print materials, including full runs of trade press and fan periodicals, yers, posters, and other publicity materials. Of particular interest to scholars are a number of early original scenarios with directors shooting notes and handbooks for the live benshi narrators of Japanese silent lms.

The Planned Community Archives Collection (PCA) has found a permanent home at George Mason University. Though placed on deposit in 1987, the collection was ofcially gifted to the George Mason University Libraries this year. The collection consists of correspondence, reports, meeting minutes, publicity, maps, architectural drawings, slides, videotapes, and photographs that chart the history of the planned community and new town movement worldwide. The PCA Collection is approximately 675 linear feet and is particularly strong in its documentation of the history of Reston, Virginia, including Reston-related oral histories, plans, photographs, and records of civic organizations. The PCA Collection also contains information from planned communities and new towns from across the United States, such as Greenbelt, Maryland, and Woodland, Texas, and communities abroad such as Peoples Freeway, Israel, and Saint Quentin, France.

The papers of poet and author Charles Bukowski (1920 94) have been acquired by the Huntington Library. Bukowski s widow 
donated a collection of his corrected drafts of novels and poems, fan letters, photographs, and audiovisual material, as well as rare editions of his books and scarce, ephemeral printings from small presses. In his poetry and prose, Bukowski used experience, emotion and imagination, along with violent and sexual imagery, to capture life at its most elemental, where there is no arti ce or posturing, but just the getting on with day-to-day survival at the harsh edge of society. Born in Germany in 1920 to an American father and German mother, Bukowski grew up in Los Angeles, enduring a childhood and youth marked by bullying from other boys and regular beatings from his abusive father. After spending several years collecting rejection slips trying to make a life as a writer, in the mid-1950s Bukowski began publishing in underground newspapers like Open City and L.A. Free Press. His rst book of poetry, Flower, Fist, and Bestial Wail, appeared in 1959. In the decade following, his work was discovered by John Martin, proprietor of the Black Sparrow Press, and the Santa Rosa-based publisher issued nearly all of his subsequent 40-plus books. In addition to such volumes of poetry as Burning in Water, Drowning in Flame: Selected Poems, 1955-1973, Bukowski wrote short stories, and such novels as Post Office (1971), Factotum (1975), Women (1978), Ham on Rye (1982), Hollywood (1989), and Pulp (1994, the year of his death). His screenplay, Barfly, based on his own life, was produced as a theatrical release in 1987 , starring Mickey Rourke and Faye Dunaway. Matt Dillon starred in a $1 \mathrm{~m}$ adaptation of Bukowski s novel Factotum that opened in August.

Works by internationally known North Carolina photographers now are on display in the Robert B. House Undergraduate Library at the University of North Carolina(UNC)-Chapel Hill. Ann Stewart, a Chapel Hill art consultant who represents the artists, donated the photos to the UNC Library. Stewart is the granddaughter of Robert B. House, chancellor of the university from 1945 to 1957 , for whom the library is named. Ten large format black-and-white prints by two of the photographers Bill Bamberger and Margaret Sartor were hung

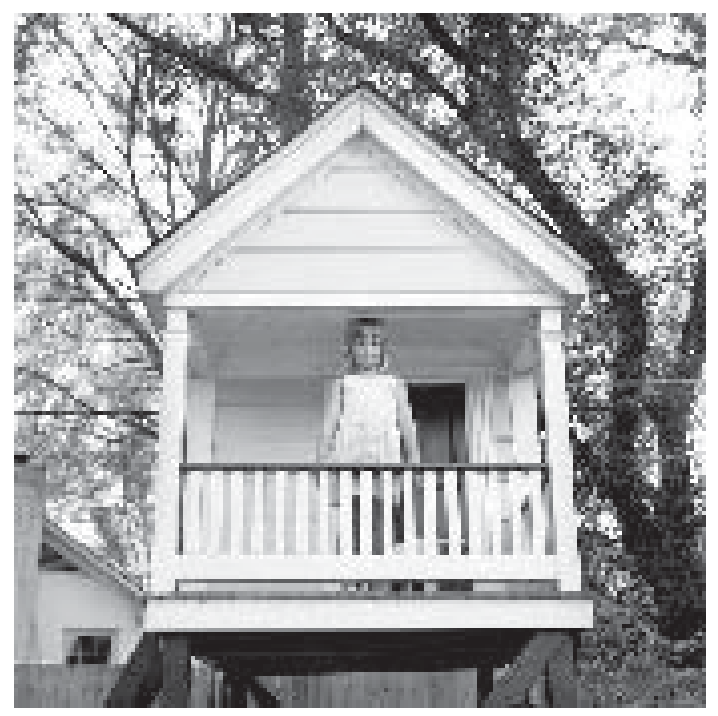

"Katherine in the Playhouse Built by her Father," Monroe, Louisiana, 1989, by Margaret Sartor.

in the Christopher B. Smith Instructional Lab on the library s main oor, and a 40-by-50-inch color mural by Alex Harris will join them. The photos depict scenes of the American South from the early 1980s through 2002. The photographers works are in the permanent collections of major museums, including the San Francisco Museum of Modern Art, the J. Paul Getty Museum in Los Angeles, the Museum of Modern Art and the Metropolitan Museum of Art in New York, and the North Carolina Museum of Art in Raleigh.

\section{The Kamlet Chemical Laboratories Collection,} as well as a gift to establish the Jonas Kamlet Memorial Fund, have been donated to the University of South Florida. In addition to preserving Kamlets scienti c achievements, the fund will reveal the research of the chemist and inventor. The collection is approximately 400 linear feet and was delivered in nearly three dozen ling cabinets. The collection documents basic chemistry advancement from 1940 to the mid-1960s. As a consulting chemist, Kamlet produced more than 100 patents, including the blood glucose meter, which is today s standard approach for diabetes testing. Kamlet collaborated with Miles Laboratories, where he developed a process for recovering paper-mill wastes. He obtained a patent for the production of d-tartaric acid, a pregnancy test strip, and other inventions. $\boldsymbol{n}$ 